Identification of a criminal

by $D$ N A typing in a rape

case in Rio de Janeiro, Brazil

D N A D iagnostic Laboratory, Instituto de Biologia, U niversidade Estadual do Rio de Janeiro, Rio de Janeiro, Brazil
- Andréa Carla de Souza Góes

- Dayse Aparecida da Silva

- Cristiane Santana Domingues

- João M arreiro Sobrinho

- Elizeu Fagundes de Carvalho

hand, ST R (short tandem repeats) analysis is a simplemethodology that works even with poor and degraded DNA. As a disadvantage, it is known that a STR locus is not as polymorphic as a VN TR one. ${ }^{6}$

In this report, we describe the usefulness of both methodologies for typing samples collected from a four-month-old fetus conceived in a rape case. The victim, a 14year-old girl with a genetic disorder (D own's Syndrome), was raped in Rio de Janeiro, Brazil, in 1998. The crime was only notified some months later when the pregnancy became evident, and therefore DNA sperm typing was not carried out to identify therapist from among the suspects. The victim had obtained judicial authorization for an abortion and, in order to identify the biological father of the fetus, we typed the aborted fetus, its mother (the victim) and four suspects in the rape case. We combined the STR and VN TR analyses to increase the Paternity Index. grandfathers, brothers, sisters or uncles In the same way, the DNA profile of biological samples collected at a crime scene can be compared to that from a suspect or his relatives. The scientific knowledge gained in this area has enabled DN A typing of human remains and biological evidence to become a valid technique for human identification.

In thiscontext, polymorphic regionswithin DN A, called VN TR (variablenumber of tandem repeats), have been successfully used for D N A typing purposes for more than 10 years. ${ }^{5}$ H owever, as the analysis of VN TR loci requires largeamounts of DN A, this methodology is not so efficient for typing degraded DNA and samples with very small amounts of $D N A$, such as the DNA prepared from biological samples
............... ETHODS

DNA extraction - $50 \mu \mathrm{L}$ of blood from the victim and suspects, and skin tissue from the fetus $\left(10-20 \mathrm{~mm}^{2}\right)$, were incubated for 15 18 hours in $500 \mu \mathrm{L}$ lysis buffer ( $10 \mathrm{mM}$ Tris$\mathrm{Cl} \mathrm{pH} \mathrm{7.5;} 1 \mathrm{mM}$ EDTA; $50 \mathrm{mM} \mathrm{NaCl} ; 2 \%$ SDS) containing $0.3 \mathrm{mg} / \mathrm{ml}$ proteinase $K$, at $56 \stackrel{\circ}{\circ}$. The D N A was extracted using phenol/ chloroform/isoamyl alcohol (25:24:1). Each D N A preparation was resuspended in $20 \mu \mathrm{L}$ TE buffer (10 mM Tris-Cl, 1 mM EDTA). In order to estimateD N A integrity, $1 \mu \mathrm{L}$ samples were applied to $0.8 \%$ agarose gel, with elec-

\begin{abstract}
......... ABSTSRACQT
CONTEXT: Human DNA identification is a powerful tool for paternity cases as well as for criminal investigation, in which biological evidence is typed after collection from crime scenes and for the identification of human remains.

OBJ ECTIVE: Identification of a criminal in a rape case with 4 suspects using STR and VN TR DN A analysis.

TYPE OF STUDY: Forensic DN A analysis.

SETTING: DNA Diagnostic Laboratory, Universidade Estadual do Rio de Janeiro, Brazil.

PARTICIPANTS: Blood from 4 suspects and the victim, and skin from the fetus.

PROCEDURES: Polymerase chain reaction (PCR) and restriction fragment length polymorphism (RFLP).

RESULTS: Three of the suspects were excluded and one of them was identified as the biological father of the fetus after typing with CTT and FFv Multiplexes. Complementary DN A typing at 3 VN TR loci was also carried out.
\end{abstract}

CONCLUSIONS: After typing four suspects using 6 STR loci, one of them was identified as the biological father of the fetus. In order to significantly enhance the Combined Paternity Index (PI), complementary DN A typing in 3 VN TR loci was carried out. The included suspect was found to be the biological father with a PI of 412,860 (Probability of Paternity: 99.9997\%).

KEY WORDS: Sexual abuse. Forensic DNA. STR VN TR. Paternity. 
trophoresis at $100 \mathrm{~V}$ for 15 minutes and staining with ethidium bromide $(0.5 \mu \mathrm{g} / \mathrm{ml})$. DNA quantification was carried out by measuring optical densities at $260 \mathrm{~nm}$.

PC $R$ reaction - 6 ST $R$ loci were analyzed using the FFv and CTT Multiplex silverstained systems from Promega Corporation. To a $25 \mu \mathrm{L}$ final reaction volume, $5 \mathrm{ng}$ of template D N A, $2.5 \mu \mathrm{L}$ ST R 10 buffer, 2.5 $\mu \mathrm{L}$ CTT or FFv primer and $0.75 \mathrm{U}$ Taq polymerase were added. $T$ he $P C R$ reactions were performed in a Perkin-Elmer 9600 thermocycler with initial denaturation for 2 min at $96{ }^{\circ} \mathrm{C}$ followed by 10 cycles of 1

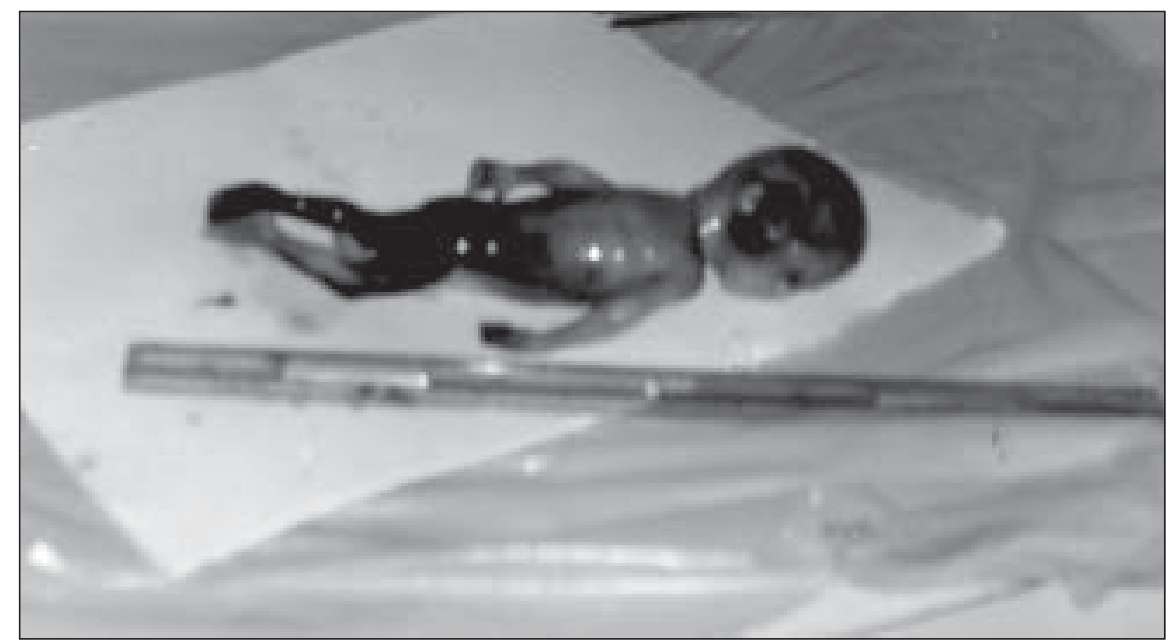

Figure 1. Aborted fetus obtained after judicial authorization.

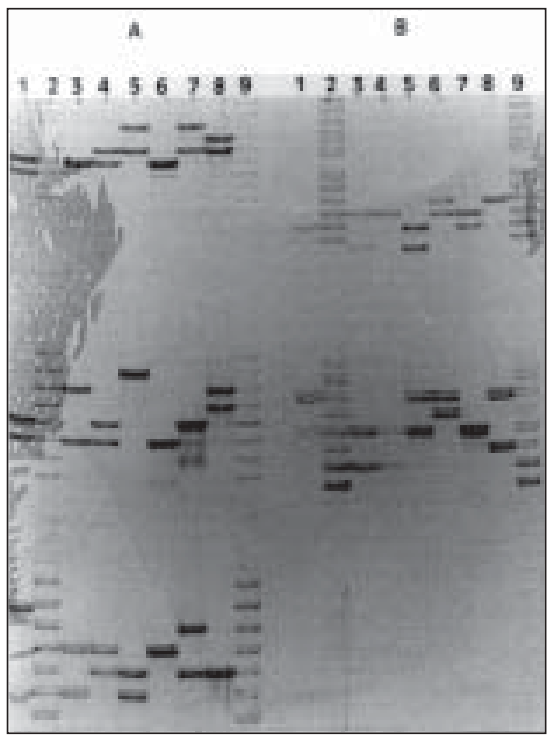

Figure 2. 4\% silver-stained polyacrylamide gel showing CTT, F13A01 and FESFPS typing of victim, fetus and suspects. PANEL A: CT T (CSF1PO, TPOX and TH 01) typing. PANEL B: F13A01 and FESFPS typing. 1- positive control; 2- ladder; 3- victim (mother); 4- fetus; 5 - Suspect \# 1; 6- Suspect \# 2; 7- Suspect \# 3; 8- Suspect \# 4; 9- ladder. $\min$ at $94 \stackrel{\circ}{\circ}, 1 \mathrm{~min}$ at $60 \stackrel{\circ}{\circ}, 1.5 \mathrm{~min}$ at $70 \stackrel{\circ}{\circ}$ and 20 cycles of 1 min at $90 \stackrel{\circ}{\circ}, 1$ $\min$ at $60 \stackrel{\circ}{\circ}$ and $1.5 \mathrm{~min}$ at $70 \stackrel{\circ}{\circ}$. The amplification products were analyzed on a $2 \%$ agararose gel.

ST R alle analysis - The amplification products were resolved on a $4 \%$ polyacrylamide gel (7 M urea; 4\% acrylamide-bisacrylamide solution; $0.5 \mathrm{TBE}$ ), using SA32 Sequencing Gel Electrophoresis Apparatus (Life Technologies). The gel was prerun for 30 minutes at $1500 \mathrm{~V}, 80 \mathrm{~W}, 40 \mathrm{~mA}$, in $0.5 \times$ TBE buffer prior to sampleloading. ThePCR products were mixed with loading buffer and
Figure 3. 6\% silver-stained polyacrylamide gel showing vWA typing of victim, fetus and suspects. 1- ladder; 2 Suspect \# 4; 3- Suspect \# 3; 4- Suspect \# 2; 5- Suspect \# 1; 6-fetus; 7- victim (mother); 8- ladder; 9- positive control.

denatured at $95 \stackrel{\circ}{ } \mathrm{C}$ for $2 \mathrm{~min}$. The gel was run for 90 min under the same conditions as above and with silver staining. ${ }^{7}$

D N A digestion with restriction enzyme $500 \mathrm{ng}$ of genomic D N A were digested with $1 \mathrm{U}$ of $\mathrm{H}$ aellI (Gibco-BRL), at $37^{\circ} \mathrm{C}$ for 12 18 hours. The restriction fragments were precipitated by adding ammonium acetate to $2.5 \mathrm{M}$ final and 2 volumes of ethanol. After incubation at $-20 \stackrel{\circ}{\circ}$ for 2 hours, the D N A was recovered by centrifugation in a microfuge (maximum speed, for 10 minutes) and resuspended in $20 \mu \mathrm{L}$ loading buffer $(10 \mathrm{mM}$ Tris-Cl pH 7.5; 1 mM EDTA; 20\% Ficoll; $0.02 \%$ BPB; $0.02 \%$ XC-FF solution).

Electrophoresis and D NA transfer - The fragments were separated on $0.8 \%$ agarosegel with $1 \times$ TBE buffer for 24 hours at 20V. The gel was denatured using alkali treatment and transferred to nylon membrane by the Southern method. ${ }^{8}$

$\mathbf{H}$ ybridization - Sequential hybridization was developed as recommended by the manufacturers, using alkaline-phosphatase chemiluminescence labeled probes AC 415, CEB42 and TBQ 7.

Statistical analysis- A data bank from the population of the State of Rio de Janeiro was utilized. ${ }^{9,10}$

\section{RESU LTS}

The silver-stained polyacrylamide gel (Figures 2 and 3) showed that three of the suspects were excluded and only suspect \# 3 was included as the biological father of the fetus after typing with CT T and FFv M ultiplexes. The typed alleles at the 6 ST R loci for each suspect are summarized in Table 1. Suspect \# 1 was excluded because of the TPOX, F13A01 and vWA loci. Suspect \# 2 was excluded because of 5 of the 6 ST R loci, whereas suspect \# 4 was excluded because of 4 loci. In addition, in order to increase the PI for suspect \# 3, we also typed the victim, fetus and suspect \# 3, using 3 VNTR loci. The results from the VNTR analysis are summarized in Table 1. A cumulative paternity index of 412,860 was obtained by combining theST R and VN TR analysis. The probability of paternity was $99.9997 \%$.

DISCUSSION

$\mathrm{N}$ owadays, in rape cases, routine vaginal swabs can be taken from the victims to carry out DNA analysis. The genetic profiles and even the number of criminals involved in sexual crimes can be determined from the 
sperm DNA typing. In this case, the crime was not reported to the authorities immediately after the rape occurred. As sperm was not collected to compare the spermatozoa profile to those of the four suspects, the fetus DNA profile was compared to them. This procedure would be expected to indicate whether at least one of the suspects was the biological father of the fetus. In view of this, all four suspects were tested to identify the biological father of the aborted fetus (Figure 1). We utilized as strategy a combination of VNTR and STR analysis to carry out the Paternity testing. The paternal alleles of the fetus were found in the genomic material of suspect \#3 at all examined loci as would be expected for a father and his child.

CONCLUSIONS

Suspect \#3 was found to bethebiological father of the fetus with a $C$ ombined Paternity Index of 412,860 and a Probability of Paternity of $99.9997 \%$.

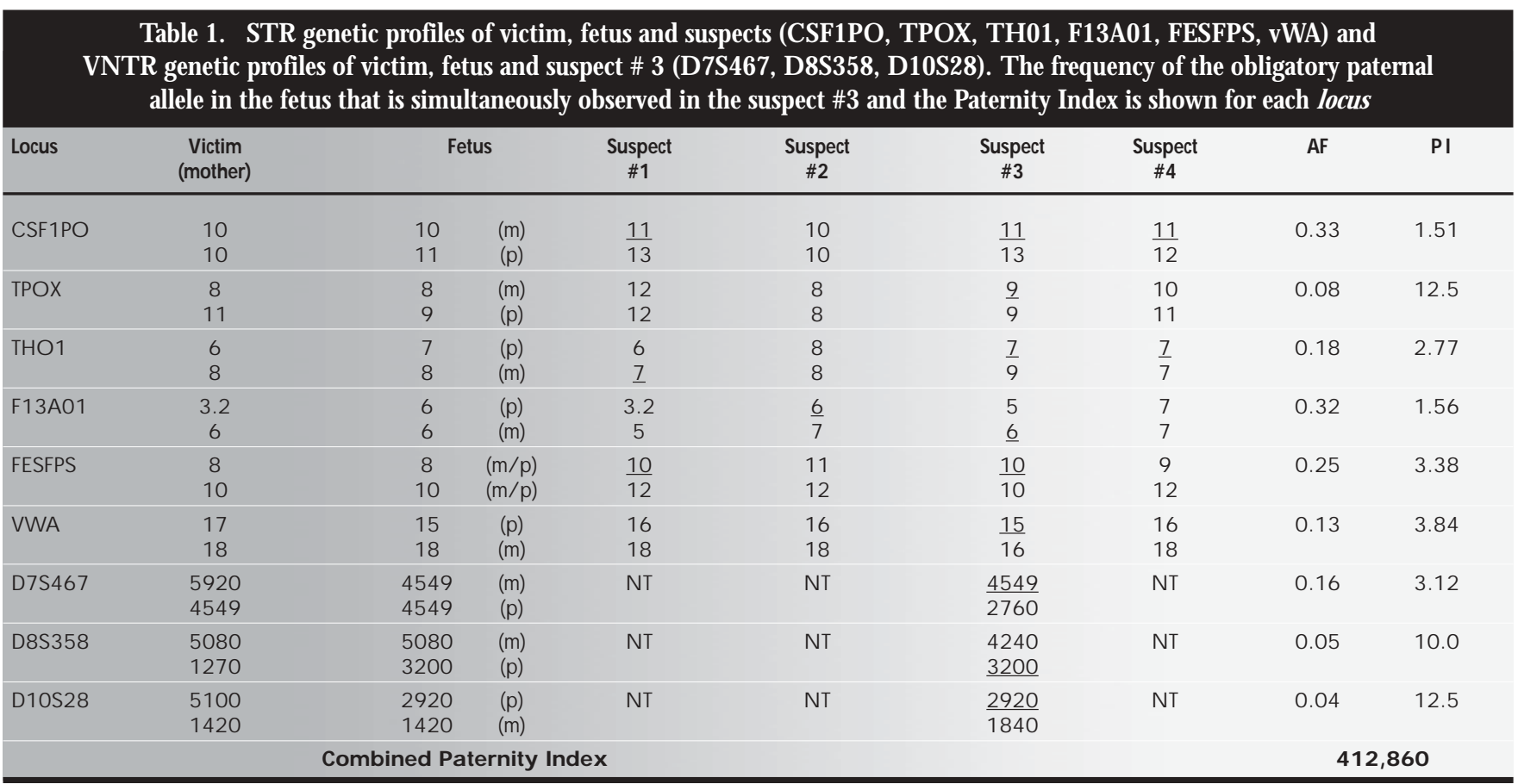

The suspect's alleles coincident with the obligatory paternal alleles are underlined; AF - Fetus and suspect \#3 coincident allele frequency; PI - Paternity Index; N T - N ot typed; $m$ - maternal allele; $p$ - obligatory paternal allele.

1. JeffreysAJ, Wilson V, Thein SL. Individual Specific Fingerprint of Human DN A. N ature 1985;316:76-9.

2. BolesTC, Snow CC, Stover E. Forensic D N A testing on skeletal remains from mass graves: a pilot project in Guatemala. Journal of Forensic Sciences 1995;3:349-55.

3. Ginther C, Issel A, Tarver L, King M C. Identifying individual by sequencing mitochondrial D N A from teeth. $N$ ature Genetics 1992;135-8.

4. H iguchi $\mathrm{R}$, von Beroldingen $\mathrm{CH}$, Sensabaugh $\mathrm{G} F$, Erlich $\mathrm{HA}$. D N A typing from single hair. N ature 1988;332:543-46.
5. Jeffreys AJ, Brookfield JFY, Semeonoff R. Positiveidentification of an immigration test case using human DNA fingerprints. N ature 1985;317:818-19.

6. Lins AM, Sprecher CJ, Puers C, Schumm JW. M ultiplex sets for theamplification of polymorphic short tandem repeat loci - silver stain and fluorescence detection. Biotechniques 1996;20:882-9.

7. U ser Guide of Promega Corporation, revised in $2 / 98$.

8. Southern EM. Detection of specific sequences among DNA fragments separated by gel electrophoresis. Journal of M olecular Biology 1975;98:520-7.
9. Silva D A, Chakraborty R, Stivers D N, Zhong Y, C arvalho EF, Crouse CA. Validation of CODIS 13 loci and pentanucleotide (Penta E) for three Brazilian populations (Rio black, non-black and Brazilian Central West population), a statistical and comparative study. 10th International Symposium on H uman Identification - O rlando, EU A. 1999.

10. Carvalho EF, D omingues C, M arreiro J, et al. Brazilian population database: VN TR alleles frequency distribution on black and nonblack population samplesfrom Rio dejanero, Brazil. 9th International Symposium on H uman Identification - O rlando, EUA. 1998. 
..Pu bl ish ing in for mat ion.

Acknow ledgments: This work was supported by FA PERJ.

Andréa Carla de Souza Góes, MD, MS. DN A Diagnostic Laboratory, Instituto de Biologia, Universidade Estadual do Rio de Janeiro, Rio de Janeiro, Brazil.

Dayse Aparecida da Silva, MD, MS. DN A Diagnostic Laboratory, Instituto de Biologia, Universidade Estadual do Rio de Janeiro, Rio de Janeiro, Brazil.

Cristiane Santana Domingues, MD, BS. DN A Diagnostic Laboratory, Instituto de Biologia, Universidade Estadual do Rio de Janeiro, Rio de Janeiro, Brazil.

João Marreiro Sobrinho, MD, BS. DNA Diagnostic Laboratory, Instituto de Biologia, Universidade Estadual do Rio de Janeiro, Rio de Janeiro, Brazil.

Elizeu Fagundes de Carvalho, MD, PhD. DN A Diagnostic Laboratory Director, Instituto de Biologia, Universidade Estadual do Rio de Janeiro, Rio de Janeiro, Brazil.

Sources of funding: supported by FAPERI (grant \# E-26/ $170.412 / 99)$ and Universidade Estadual do Rio de Janeiro (UERJ).

Conflict of interest: $N$ ot declared

Date of first submission: 300 ctober 2000

Last received: 29 January 2002

Accepted: 7 February 2002

Address for correspondence

Andréa Carla de Souza Góes

Rua 19 de Fevereiro, 100 / 505 - Botafogo

Rio de Janeiro/RJ - Brasil - CEP 22280-030

E-mail: acgoes@uerj.br

RESU MO

CONTEXTO : A identificação humana por DNA é uma ferramenta poderosa para casos de paternidade, assim como investigação criminal pela tipagem de evidências biológicas coletadas em cenas de crime e identificação de restos mortais.

O BJETIVO : I dentificação de criminoso em caso de estupro com quatro suspeitos utilizando análise de STR eVNTR no DNA.

TIPO DE EST UD O: Análise de DNA forense.

LOCAL: Laboratório de D iagnósticos por D N A, Universidade do Estado do Rio de Janeiro, Brasil.

PART ICIPAN TES: Sangue de quatro suspeitos e vítima e pele do feto.

PRO CEDIMENTOS: Reação em cadeia da polimerase (PCR) e polimorfismo de tama- nho de fragmentos de restrição (RFLP).

RESU LTAD O S: Três suspeitos foram excluídos e um suspeito foi incluído como pai biológico do feto apóstipagem com os M ultiplexes CTT e FFv. U m teste complementar com 3 loci VNTR também foi realizado.

CONCLUSÃO: Após a tipagem de quatro suspeitosem 6 loci ST $R$, um delesfoi incluído como o pai biológico do feto. Com o objetivo de aumentar o Índice de Paternidade Combinado (PI), um teste complementar com 3 loci VNTR foi realizado. 0 suspeito foi incluído como pai biológico apresentando Índice de Paternidade de 412.860 (probabilidade de paternidade: 99,9997\%).

PALAVRAS-CHAVE: Abuso sexual. DNA forense. ST R. VNTR. Paternidade. 